\title{
Editorial
}

Journal of Innate

Immunity

Published online: December 2, 2009

DOI: $10.1159 / 000264603$

\section{Innate Immunity and Airway Inflammation}

In this issue of the Journal of Innate Immunity, we present a focus on innate immunity and airway inflammation that will highlight the state of the art in this exciting new area of immunological research. First, an authoritative overview by Lanckacker et al. [1] critically discusses how the innate immune system of the lung deals with the onslaught of 'real-world' exposures to environmental atmospheric pollutants in which innate immunity is evolutionary ill prepared to respond to such challenges. Second, an equally authoritative review by Horner [2] discusses how the innate immune system senses and responds to the indoor ambient environment of households. Horner challenges current hypotheses of immune tolerance and protective immunity in allergic inflammation and instead proposes a new paradigm by which ligands occupying airborne pattern recognition receptors influence the generation of allergic diseases of the lung. In a related article, Eisen [3] critically analyzes how deficiency in mannose-binding lectin (an important innate immune pattern recognition receptor) enhances host susceptibility to lower respiratory tract infections. In addition, three key research articles discuss novel systems and mechanisms of innate immune defense against respiratory infections and immunoregulation. In the first of these articles, Williams et al. [4] describe a novel role for the transmembrane Mucl mucin receptor in innate immunity. Genetic deletion of Mucl promoted a heightened functional response of dendritic cells in response to Tolllike receptors TLR4 and TLR5 signaling pathways, suggesting a previously underappreciated role for Mucl in regulating innate immune responses of conventional myeloid pulmonary dendritic cells. In the following article, Pesce et al. [5] provide new information on the role of CpG-containing oligonucleotides as highly effective mucosal adjuvants in the immune therapy of respiratory infections, which they propose to be partly dependent on the de novo recruitment of dendritic and natural killer cells. Finally, Bober et al. [6] describe collagen VI as a novel target structure for adherence of bacterial pathogens that play important roles in airway infections.

Marc A. Williams, Research Triangle Park, N.C., USA

\section{References}

1 Lanckacker EA, Robays LJ, Joos GF, Vermaelen KY: A new danger in the air: how pulmonary innate immunity copes with manmade airborne xenobiotics. J Innate Immun 2010;2:96-106.

2 Horner AA: Regulation of aeroallergen immunity by the innate immune system: laboratory evidence for a new paradigm. J Innate Immun 2010;2:107-113.
3 Eisen DP: Mannose-binding lectin deficiency and respiratory tract infection. J Innate Immun 2010;2:114-122.

4 Williams MA, Bauer S, Lu W, Guo J, Walter S, Bushnell TP, Lillehoj EP, Georas SN: Deletion of the mucin-like molecule Mucl enhances dendritic cell activation in response to Toll-like receptor ligands. J Innate Immun 2010;2:123-143.
5 Pesce I, Monaci E, Muzzi A, Tritto E, Tavarini S, Nuti S, De Gregorio E, Wack A: Intranasal administration of $\mathrm{CpG}$ induces a rapid and transient cytokine response followed by dendritic and natural killer cell activation and recruitment in the mouse lung. J Innate Immun 2010;2:144-159.

6 Bober M, Enochsson C, Collin M, Mörgelin $\mathrm{M}$ : Collagen VI is a subepithelial adhesive target for human respiratory tract pathogens. J Innate Immun 2010;2:160-166.

\begin{tabular}{ll}
\hline KARGER & ( 2009 S. Karger AG, Basel \\
$1662-811 X / 10 / 0022-0095 \$ 26.00 / 0$ \\
Fax +41 61306 1234 \\
$\begin{array}{l}\text { E-Mail karger@karger.ch } \\
\text { www.karger.com }\end{array}$ & $\begin{array}{l}\text { Accessible online at: } \\
\text { www.karger.com/jin }\end{array}$
\end{tabular}

